\title{
Effects of Gmelina arborea, Roxb leaf meal on egg characteristics of Coturnix coturnix japonica, Temmick
}

\author{
Asolo, Chioma Helen ${ }^{1 *}$, Okeke John Joseph ${ }^{1}$, Mayie Francis Nnamdi ${ }^{1}$, \\ Okpoko Valentine Obinna ${ }^{1}$ and Ezeanekwu Raymond Orji ${ }^{2}$
}

\author{
${ }^{1}$ Department of Zoology, Faculty of Biosciences, Nnamdi Azikiwe University, Awka, Nigeria. \\ ${ }^{2}$ Department of Microbiology, Faculty of Natural Sciences, Chukwuemeka Odimegwu University, Uli, Anambra State, Nigeria. \\ ${ }^{*}$ Corresponding author. Email: asohelecy@gmail.com
}

Copyright (C) 2021 Asolo et al. This article remains permanently open access under the terms of the Creative Commons Attribution License 4.0, which permits unrestricted use, distribution, and reproduction in any medium, provided the original work is properly cited.

Received 24th February, 2020; Accepted 12th March, 2020

\begin{abstract}
A thirty-six weeks feeding trial was conducted to determine the effect of inclusion of varying levels of Gmelina arborea on egg characteristics, using two (2) weeks old Japanese quail (Coturnix coturnix japonica). Ninety-six birds were allocated to four dietary treatment groups with three (3) replicates of eight (8) birds each in a completely randomized design comprising of control (C) containing $0 \mathrm{~g} / \mathrm{kg} ; \mathrm{T}_{1}, 50 \mathrm{~g} / \mathrm{kg} ; \mathrm{T}_{2}, 100 \mathrm{~g} / \mathrm{kg}$ and $\mathrm{T}_{3}, 150 \mathrm{~g} / \mathrm{kg}$ of Gmelina arborea leaf meal. Feed and water were provided throughout the experimental period. Egg characteristics were the response criteria that were monitored and subjected to a one-way anova. There were significant $(p<0.05)$ differences observed between treatments for mean egg number and egg shell weight, while no differences $(p>0.05)$ were observed between treatments for eggs composition, weight of eggs, egg shell thickness, egg length, egg width, albumen height, albumen width, albumen weight, yolk height, yolk width, yolk weight. From this study, the egg laying performance and characteristics of eggs laid by birds suggested that among the treatments, up to $50 \mathrm{~g} / \mathrm{kg}$ of Gmelina arborea leaf meal could be successfully included in quails' diets without any adverse effect.
\end{abstract}

Keywords: Albumen, egg, Gmelina arborea, weight, yolk.

\section{INTRODUCTION}

The problem of food deficiency in underdeveloped and developing countries has continued to worsen due to the perpetual increase in human population (Fatokun et al., 2013). The Japanese quails (Coturnix coturnix japonica) have the potential to serve as an excellent and cheap source of animal protein for Nigerians (Babangida and Ubosi, 2006; Ani et al., 2009). Distinct characteristics of the Japanese quail include rapid growth thus enabling the quail to be ready for consumption at 5 to 6 weeks of age, early sexual maturity, short generation interval, disease resistance, less capital requirement, high rate of lay and much lower feed and space requirement than domestic fowl (Adeogun and Adeoye, 2004).

Livestock farmers, especially those in Nigeria and neighboring countries are faced with the problem of continuous inadequacy of feed ingredients (Fatokun et al., 2013). This arises from the ever-increasing needs of men for the same livestock feed ingredients for his food and industrial raw materials used in the production of other materials like maize, millet, sorghum, soybean, groundnut, cassava and other tubers (Fatokun et al., 2013). Gmelina arborea $R$. is one of the such novel feed stuffs (Annongu and Folorunso, 2003). The potential of leaf meals from these tropical trees and shrubs to yield relatively higher levels of crude protein and minerals, and lower crude fiber levels than tropical grasses has also been recognized (Esonu et al., 2003; Fasina et al., 2004; Okagbare et al., 2004a; Amata, 2010). The amount of research carried out with nonconventional feeding materials could have a major impact on livestock production but they continue to be unused, underdeveloped or underutilized. A critical factor in this regard has been the lack of proper understanding of the nutritional principles underlying their utilization (Amata and Lebari, 2011). 
The poultry egg remains an excellent source of nutrients in the normal human diet and eggs are consumed annually throughout the world. The production of good quality egg is a major concern of producers (Nworgu et al., 2012). Evaluation of the external and internal egg traits will not only be useful as a selection criterion but will also enhance economic decisions for intending backyard and/or commercial producers in this region (Obike et al., 2011). Egg quality reflects those egg characteristics that determine its acceptability to consumers (Song et al., 2000). Gmelina arborea leaf, a product of Gmelina arborea tree which is not in competition with man's dietary needs and it has been reported to enhance weight gain of small animals (Okagbare et al., 2004b). The deciduous plant, Gmelina arborea $R$. is widely distributed in the tropics of Africa and warm temperature regions. Based on the above, this research work was conducted to evaluate the effects of varying inclusion levels of Gmelina arborea leaf meal on egg characteristics of Japanese quail birds (Coturnix coturnix japonica).

\section{MATERIALS AND METHODS}

This study was carried out from March to November 2019, at the Animal house of the Zoology Department of Nnamdi Azikiwe University, Awka in Awka South Local Government Area of Anambra State, South-East of Nigeria, West Africa. The leaves were collected from Awka, monthly and were washed, air-dried at room temperature for 7 days and then milled. A total of ninetysix (96), two weeks old Japanese quail birds were used for the study. This study lasted for 36 weeks. The experimental cage was the colony closed cage housing system. Each of the 4 tiers had 3 partitions representing 4 treatment and 3 replicates respectively. The animals were allocated into four groups with three replicates of eight birds each with the ratio of 1 male to 3 females (Momoh et al., 2014) on live weights. The housing groups were based on the level of Gmelina arborea leaf meals inclusions of $\mathrm{C}$ $=0 \mathrm{~g} / \mathrm{kg}, T_{1}=50 \mathrm{~g} / \mathrm{kg}, T_{2}=100 \mathrm{~g} / \mathrm{kg}$ and $T_{3}=150 \mathrm{~g} / \mathrm{kg}$. The feeds used during the study were formulated feeds with Gmelina arborea leaf meal as presented in Table 1. Feed and water were provided throughout the experimental period. The birds were fed twice daily (Morning and evening). Artificial lighting was used to provide the birds with 24 hours light and later, 16 hours until the experiment was over during the whole experimental period (Lima et al., 2016).

\section{Data collection}

The eggs laid by the birds were collected in labeled egg crates in the morning and were kept in baskets at room temperature daily. The number of eggs was recorded daily, and the other external and internal egg characteristics were obtained weekly. External eggs characteristics such as the number of the eggs, egg weight, length, width, egg shell weight and thickness (Tuleun et al., 2013) and internal egg characteristics such as the albumen height, width, weight, yolk height, width and weight (Tuleun et al., 2013) were measured using three eggs per replicate. Phytochemical tests for the presence or absence of alkaloid, saponnin, flavanoid, tannin and steroid were carried out on the methanolic extract of Gmelina arborea leaves using the procedure outlined by Harbone (1998). The feed and egg samples from different treatments were analyzed for proximate composition (AOAC, 1990) for moisture content (MC), crude protein (CP), crude fat (CF), total ash (TA), crude fibre $(F)$ and carbohydrates $(C)$.

\section{Statistical analysis}

The data collected were subjected to the one-way Analysis of Variance (ANOVA) using SPSS (2007). The least significant difference (LSD) was used to separate mean significant differences between treatments at the $5 \%$ significant level.

\section{RESULTS AND DISCUSSION}

The feed with $150 \mathrm{~g} / \mathrm{kg}$ of Gmelina arborea reveals the highest values for ash $(13.70 \%)$, crude fat $(6.10 \%)$ and crude protein (18.90\%). The crude protein values are in line with the crude protein recommended by Murakami et al. (1993b) who recommended $18 \%$ crude protein and lower than $20 \%$ recommended by NRC (1994) and Babangida and Ubosi (2006) for production period of quail birds but are higher than the crude protein (17\%) recommended by Bawa et al. (2011). The higher crude protein content with increasing inclusion levels is not surprising as Okagbare et al. (2004a), Amata and Lebari (2011) and Aye (2016) reported that the protein content of Gmelina arborea is high thus Gmelina arborea leaf meal may be an important source of dietary protein for both human and livestock judging from its proximate composition. This study agrees with Nieman et al. (1992) who reported that in animals, a $\mathrm{Ca} / \mathrm{P}$ ratio above 2.0 helps to increase the absorption of Calcium in the small intestine. Food is considered "good", if the ratio $\mathrm{Ca} / \mathrm{P}>1$ and "poor" if $\mathrm{Ca} / \mathrm{P}<0.05$ (Nieman et al., 1992) while $\mathrm{Na} / \mathrm{P}$ ratio is 0.06 . The $\mathrm{Ca} / \mathrm{P}$ values for all the treatments were all greater than $1(\mathrm{Ca} / \mathrm{P}>1)$ and their $\mathrm{Na} / \mathrm{P}$ values were equal and less than 0.06 as seen in Table 2 .

\section{Phytochemical composition of Gmelina arborea}

In this study, result of the phytochemical composition of the Gmelina arborea showed the presence of flavonoid, saponins, alkaloid, phenol and steroid with tannin, phenol and Saponin strongly present, flavanoid, steroid and alkaloid moderately present. This concur with the findings of Aye (2016) and Osakwe (2003) who revealed 
Table 1. Feed formulation for quail birds

\begin{tabular}{lcccc}
\hline Ingredients & $\mathbf{C}(\mathbf{0 g} / \mathbf{k g})$ & $\mathbf{T}_{\mathbf{1}}(\mathbf{5 0} \mathbf{g} / \mathbf{k g})$ & $\mathbf{T}_{\mathbf{2}}(\mathbf{1 0 0} \mathbf{g} / \mathbf{k g})$ & $\mathbf{T}_{\mathbf{3}}(\mathbf{1 5 0} \mathbf{g} / \mathbf{k g})$ \\
\hline G.arborea & 0.00 & 5.00 & 10.00 & 15.00 \\
Maize & 45.02 & 45.02 & 45.02 & 45.02 \\
Wheat offal & 10.00 & 10.00 & 10.00 & 10.00 \\
Soya Beans & 11.76 & 11.76 & 11.76 & 11.76 \\
Groundnut Cake & 23.52 & 23.52 & 23.52 & 23.52 \\
Bone Meal & 3.00 & 3.00 & 3.00 & 3.00 \\
Limestone & 6.00 & 6.00 & 6.00 & 6.00 \\
Salt & 0.20 & 0.20 & 0.20 & 0.20 \\
Methionine & 0.15 & 0.15 & 0.15 & 0.15 \\
Lysine & 0.10 & 0.10 & 0.10 & 0.10 \\
Premix & 0.25 & 0.25 & 0.25 & 0.25 \\
\hline
\end{tabular}

Table 2. Nutrient composition of the layers feed with varying levels of Gmelina arborea fed to quail birds.

\begin{tabular}{lcccc}
\hline Analysis & $\mathbf{C}(\mathbf{0 g} / \mathbf{k g})$ & $\mathbf{T}_{\mathbf{1}}(\mathbf{5 0} \mathbf{g} / \mathbf{k g})$ & $\mathbf{T}_{\mathbf{2}}(\mathbf{1 0 0} \mathbf{g} \mathbf{k g})$ & $\mathbf{T}_{\mathbf{3}}(\mathbf{1 5 0} \mathbf{g} / \mathbf{k g}$ \\
\hline Moisture & 3.70 & 4.20 & 4.70 & 4.90 \\
Crude Fat & 4.80 & 5.60 & 5.80 & 6.10 \\
Ash & 10.50 & 12.80 & 13.40 & 13.70 \\
Protein & 17.30 & 17.80 & 18.40 & 18.90 \\
Crude Fibre & 7.70 & 6.90 & 6.10 & 5.40 \\
Carbohydrate & 55.90 & 52.70 & 51.60 & 50.90 \\
Ca/P & 1.68 & 1.88 & 1.86 & 1.79 \\
$\mathrm{Na} / \mathrm{P}$ & 0.04 & 0.05 & 0.06 & 0.06 \\
\hline
\end{tabular}

condensed quantity of tannin and other anti-nutritional substances in their biomass which affect the optimal utilization by animals. This is in line with Okpara et al. (2016) who also revealed the presence of tannin, alkaloid, saponin, flavonoid and steroid depicting potential toxicity of the feed resources, thereby they adopted in their study that air-drying did not reduce the nutritive values but reduced effect of the anti-nutritional factors (ANF's). This is also in line with the findings by Iswarya et al. (2017) who reported that Gmelina arborea is rich in phenol, saponin, alkaloid, tannis, flavonoid and steroid content revealing that it is appropriate to define that the presence of such phytochemicals which make Gmelina arboreaa potential plant for various pharmaceutical and medical purposes. All these could have attributed to the healthy status of the birds throughout the study, though it was observed that four birds died from the control diet treatment. This mortality was not associated to the dietary treatment of Gmelina arborea, so lack of mortality among the quail layers fed air-dried Gmelina arborea confirms that airdrying was effective in detoxifying antinutritional constituents to a safety level.

\section{Proximate analyses of the eggs}

The result of the proximate composition showed that quail eggs contained crude protein, crude fat, ash, crude fibre content, moisture content and carbohydrate as the quails were fed with the dietary treatments as represented in Table 3. There was no significant difference $(p>0.05)$ in the proximate composition of quail eggs from quails subjected to different dietary treatments with $p$-values $=0.975,0.986$, $0.973,0.192,1.000,0.913$ respectively. The values of crude protein obtained were higher than the values as reported by Dudusola (2010) but lower than values reported by Tunsanrinkan et al. (2013) and Thomas et al. (2016). The result of this concurs with the findings of Saraswati et al. (2013) who reported that quails fed high protein ration had lower egg protein content as compared to those fed with high carbohydrate and low protein ration. This agrees with the findings of Amobi et al. (2014) that the proximate composition indices are the reflections of the effect of dietary treatment on the animals in terms of the type and amount of feed ingested.

\section{Effect of Gmelina arborea leaf meal on external characteristics of eggs}

The result of the external characteristics of eggs laid by quails subjected to the dietary treatments showed that there was a significant $(p<0.05)$ difference in terms of egg number and eggshell weight of the quails among each 
Table 3. Proximate composition of the eggs laid by quails fed with different inclusions of Gmelina arborea leaf meal.

\begin{tabular}{lcccc}
\hline Analysis & $\mathbf{C}(\mathbf{0 g} / \mathbf{k g})$ & $\mathbf{T}_{\mathbf{1}}(\mathbf{5 0} \mathbf{g} / \mathbf{k g})$ & $\mathbf{T}_{\mathbf{2}}(\mathbf{1 0 0} \mathbf{g} / \mathbf{k g})$ & $\mathbf{T}_{\mathbf{3}}(\mathbf{1 5 0} \mathbf{g} / \mathbf{k g})$ \\
\hline Moisture & $72.09 \pm 1.99^{\mathrm{a}}$ & $72.13 \pm 0.97^{\mathrm{b}}$ & $72.18 \pm 2.95^{\mathrm{c}}$ & $72.22 \pm 2.87^{\mathrm{d}}$ \\
Crude Fat & $10.17 \pm 0.55^{\mathrm{a}}$ & $10.03 \pm 1.25^{\mathrm{b}}$ & $9.92 \pm 0.37^{\mathrm{c}}$ & $9.87 \pm 1.37^{\mathrm{d}}$ \\
Ash & $1.05 \pm 0.08^{\mathrm{a}}$ & $1.04 \pm 0.03^{\mathrm{b}}$ & $1.02 \pm 0.13^{\mathrm{c}}$ & $1.02 \pm 0.11^{\mathrm{d}}$ \\
Protein & $12.28 \pm 0.37^{\mathrm{a}}$ & $12.35 \pm 0.72^{\mathrm{b}}$ & $12.41 \pm 0.17^{\mathrm{c}}$ & $12.46 \pm 0.60^{\mathrm{d}}$ \\
Crude Fibre & $0.59 \pm 0.04^{\mathrm{a}}$ & $0.56 \pm 0.03^{\mathrm{b}}$ & $0.54 \pm 0.07^{\mathrm{c}}$ & $0.51 \pm 0.03^{\mathrm{d}}$ \\
Carbohydrate & $3.82 \pm 0.34^{\mathrm{a}}$ & $3.89 \pm 0.16^{\mathrm{b}}$ & $3.93 \pm 0.32^{\mathrm{c}}$ & $3.98 \pm 0.22^{\mathrm{d}}$ \\
\hline
\end{tabular}

$a, b, c, d ;$ Means with different superscript on the same row do not differ, significantly $(p>0.05)$.

Table 4. Effect of Gmelina arborea leaf meal on external and internal characteristics of eggs laid by quails.

\begin{tabular}{lllll}
\hline Parameters & $\mathbf{C}(\mathbf{0} \mathbf{g} / \mathbf{k g})$ & $\left.\mathbf{T}_{\mathbf{1}} \mathbf{( 5 0} \mathbf{g} / \mathbf{k g}\right)$ & $\mathbf{T}_{\mathbf{2}}(\mathbf{1 0 0} \mathbf{g} / \mathbf{k g})$ & $\mathbf{T}_{\mathbf{3}}(\mathbf{1 5 0} \mathbf{g} / \mathbf{k g})$ \\
\hline Egg Number & $30.78 \pm 0.35^{\mathrm{a}}$ & $34.71 \pm 1.38^{\mathrm{a}}$ & $26.50 \pm 0.93^{\mathrm{a}}$ & $23.87 \pm 1.33^{\mathrm{a}}$ \\
Egg weight $(\mathrm{g})$ & $9.72 \pm 0.08$ & $9.65 \pm 0.22$ & $9.44 \pm 0.10$ & $9.60 \pm 0.61$ \\
Egg Shell Thickness $(\mathrm{mm})$ & $1.10 \pm 0.04$ & $1.12 \pm 0.02$ & $1.11 \pm 0.02$ & $1.12 \pm 0.04$ \\
Egg Shell Weight $(\mathrm{g})$ & $0.92 \pm 0.01^{\mathrm{b}}$ & $0.93 \pm 0.01^{\mathrm{b}}$ & $0.92 \pm 0.02^{\mathrm{b}}$ & $0.93 \pm 0.06^{\mathrm{b}}$ \\
Egg Length (cm) & $3.02 \pm 0.0$ & $3.01 \pm 0.05$ & $2.98 \pm 0.05$ & $3.00 \pm 0.10$ \\
Egg Width (cm) & $2.34 \pm 0.03$ & $2.36 \pm 0.03$ & $2.34 \pm 0.02$ & $2.39 \pm 0.04$ \\
Albumen Height (cm) & $0.53 \pm 0.02$ & $0.52 \pm 0.01$ & $0.51 \pm 0.00$ & $0.53 \pm 0.04$ \\
Albumen Length (cm) & $4.56 \pm 0.15$ & $4.41 \pm 0.05$ & $4.37 \pm 0.08$ & $4.50 \pm 0.30$ \\
Albumen weight (cm) & $4.48 \pm 0.13$ & $4.61 \pm 0.08$ & $4.31 \pm 0.20$ & $4.40 \pm 0.29$ \\
Yolk Height (cm) & $1.03 \pm 0.01$ & $1.02 \pm 0.02$ & $1.01 \pm 0.01$ & $1.04 \pm 0.05$ \\
Yolk Weight $(\mathrm{cm})$ & $3.44 \pm 0.11$ & $3.45 \pm 0.01$ & $3.45 \pm 0.16$ & $3.46 \pm 0.17$ \\
Yolk Width $(\mathrm{cm})$ & $2.41 \pm 0.06$ & $2.46 \pm 0.04$ & $2.42 \pm 0.04$ & $2.45 \pm 0.04$ \\
\hline
\end{tabular}

a,b; Means with same superscript on the same row differ, significantly $(p<0.05)$.

dietary treatment while there was no significant $(p>0.05)$ difference in the terms of egg weight, eggshell thickness, egg length and egg width of the eggs laid by quails among each dietary treatments.

This result of egg number is also in line with the finding of Saraswati et al. (2013) who reported significant $(p<0.05)$ effect of dietary treatment on egg production number as their study revealed that quails fed high carbohydrate ration had higher total number of production until 9 months of age as compared to those fed high protein ration and that the increase in total number of egg production did not decrease egg quality as indicated by egg weight of egg laid by quails.

The $0 \mathrm{~g} / \mathrm{kg}(\mathrm{C})$ of Gmelina arborea that produced the highest mean weight of quail birds still gave the highest mean egg weight which agrees with Lin et al. (2004) and Bawa et al. (2011) who reported that egg mass/weight can be used as criterion in assessment of nutritional status, especially if they are obtained from birds of the same age, breed and health status. Whereas the overall mean weight of eggs in all the treatments were higher than $9.3 \mathrm{~g}$ but lower than $10 \mathrm{~g}$ recommended by Yamane et al. (1979) and Hubrecht and Kirkwood (2010), respectively.

The result of egg shell weight obtained showed significant difference $(p<0.05)(P=0.000)$ among the dietary treatments. This result is in line with the finding of Hemid et al. (2010) who reported significant $(p \leq 0.05)$ effect of dietary treatment on shell weight of egg laid by quails.

The result of egg shell thickness obtained showed no significant difference $(p>0.05) \quad(P=0.930)$ among the dietary treatments. No specific trend was observed among the treatments means so this supports the report of Salah Uddin et al. (1991) and Murakami et al. (1993b) which showed that shell thickness was not affected by dietary protein levels. This study is in line with the finding of Njoya (1995) and also Tuleun and Dashe (2010) who reported no significant $(p>0.05)$ effect of energy intake on shell thickness.

The result of egg length obtained showed no significant difference $(p>0.05) \quad(p=0.930)$ among the dietary treatments. This result is not in line with the finding of Hemid et al. (2010) who reported significant ( $p \leq 0.05)$ effect of dietary treatment on egg length of egg laid by quails.

The result of egg width obtained showed no significant difference $(p>0.05)(p=0.930)$ among the dietary treatments. This result is in line with the finding of Hemid et al. (2010) who reported insignificant $(p>0.05)$ effect of dietary treatment on egg width of egg laid by quails. 


\section{Effect of Gmelina arborea leaf meal on internal characteristics of eggs laid by quails}

The result of the internal characteristics of eggs laid by quails subjected to the dietary treatments showed that there was no significant difference $(p>0.05)$ in terms of albumen height, albumen length, albumen weight, yolk height, yolk weight and yolk width among each dietary treatment.

The result of albumen height obtained showed no significant difference $(p>0.05)(P$-value $=0.823)$ among the dietary treatments. This result is not in line with the finding of Hemid et al. (2010) who reported significant ( $p \leq 0.05)$ effect of dietary treatment on albumen height. This result is in line with the finding of Tuleun and Dashe (2010) who reported no significant $(p>0.05)$ influence with dietary treatment of toasted mucuna on albumen height of egg laid by quails. But it is not in line with finding by Tuleun et al. (2013) who reported significant $(p<0.05)$ effect of dietary treatment on albumen height of eggs laid by quails.

The result of albumen width obtained showed no significant difference $(p>0.05)(p$-value $=0.963)$ among the dietary treatments. This result is not in line with the finding of Tuleun and Dashe (2010) who reported significant $(p<0.05)$ influence with dietary treatment of toasted mucuna on albumen width of egg laid by quails.

The result of albumen weight obtained showed no significant difference $(p>0.05)(p$-value $=0.444)$ among the dietary treatments. This result is in line with the finding of Hemid et al. (2010) who reported no significant ( $p>0.05)$ change with dietary treatment on albumen weight of egg laid by quails.

The result of yolk height obtained showed no significant difference $(p>0.05)(p$-value $=0.993)$ among the dietary treatments. This result is in line with the finding of Tuleun and Dashe (2010) who reported no significant $(p>0.05)$ effect with dietary treatment of toasted mucuna on yolk height of quails. But it is not in line with finding by Tuleun et al. (2013) who reported significant $(p<0.05)$ effect of dietary treatment on yolk height of eggs laid by quails.

The result of yolk weight obtained showed no significant difference $(p>0.05)$ ( $p$-value $=0.738)$ among the dietary treatments. This result is not in line with the finding of Hemid et al. (2010) who reported significant $(p \leq 0.05)$ effect with neither pre-hatch temperature nor dietary treatment on yolk weight. This result is in line with the finding of Tuleun and Dashe (2010) who reported no significant ( $p>0.05$ ) effect with dietary treatment of toasted mucuna on yolk weight of quails. But it is not in line with finding of Tuleun et al. (2013) who reported significant $(p<0.05)$ effect of dietary treatment on yolk weight of eggs laid by quails.

The result of yolk width obtained showed no significant difference $(p>0.05)$ ( $p$-value $=0.387)$ among the dietary treatments. This result is in line with the finding of Tuleun and Dashe (2010) who reported no significant $(p>0.05)$ effect with dietary treatment of toasted mucuna on yolk width of eggs laid by quails.

\section{Conclusion}

The data obtained from the present study shows that Gmelina arborea is one of the trees with significant number and amounts of phytochemicals. Hence, the presence of rich secondary metabolite concentration can apparently make the plant a good source of nutrients. There was no observable negative effect on the health status of quails fed with the varying levels of Gmelina arborea indicating healthy effect of the Gmelina arborea for the birds since no medication was used throughout the period of study. The $50 \mathrm{~g} / \mathrm{kg}$ inclusion level of Gmelina arboreais comparable with $0 \mathrm{~g} / \mathrm{kg}$ (control) diet, it can adequately be added in quails' nutrition at the level without any negative effect.

\section{CONFLICT OF INTEREST}

The authors declare that they have no conflict of interest

\section{REFERENCES}

Adeogun, I. O., \& Adeoye, A. A. (2004). Heritability and phenotypic correlation of growth performance traits in Japanese Quails. Livestock Research of Rural Development, 16, 103.

Amata, I. (2010). Nutritive Value of the Leaves of Myrianthus arboreus. International Journal of Agricultural Research, 5(8), 576-581.

Amata, I. A., \& Lebari, T. (2011). Comparative evaluation of the nutrient profile of four selected browse plants in the tropics, recommended for use as non-conventional livestock feeding materials. African Journal of Biotechnology, 10(64), 1423014233.

Amobi, M. I., Ebenebe, C. I., Anizoba, M. A., \& Ufele, A. N. (2014). Proximate and Mineral Evaluation of the Haemolymph of two common species of snails (Achatina fulica and Archachatina marginata) fed on three selected vegetables. Proceedings of the 3rd International Conference on Giant African Land Snail. Pp.74-78.

Annongu, A. A., \& Folorunso, A. S. (2003). Biochemical evaluation of Gmelina arborea fruit meal as a swine feedstuff. Biokemistri, 15(1), 1-6.

AOAC (1990). Association of Official Analytical Chemists. 16 thEd. Washington D. C. USA.

Awa, A. A. (2000). Introduction to mini livestock development as a sustainable agricultural business. Workshop paper presented to Agricultural Development Programme (ADP) of Anambra, Imo, Rivers and Cross Rivers states.

Aye, P. A. (2016). Comparative nutritive value of Moringa oleifera, Tithonia diversifolia and Gmelina arborea leaf meals. American Journal of Food and Nutrition, 6(1), 23-32.

Babangida, S., \& Ubosi, C. O. (2006). Effect of varying dietary protein levels on the performance of Japanese quail (Coturnix coturnix japonica) in a semiarid environment. Nigeria Journal of Animal Production, 33(1), 45-52.

Bawa, G. S., Lombin, L. H., Karsin, P., Payi, E., \& Shamaki, D. (2011). Responses of Japanesequails to varying dietary protein levels in the tropics. Nigeria Journal Animal Production, 38(1), 43-54.

Dudusola I. O. (2010). Comparative evaluation of internal and 
external qualities of eggs from quail and guinea fowl. International Research Journal of Plant Science, 1(5), 112115.

Esonu, B. O., Iheukwumere, F. C., Iwuji, T. C., Akanu, N., \& Nwugo, O. H. (2003). Evaluation of Microdermis puberula leaf meal as ingredient in broiler starter diets. Nigeria Journal of Animal Production, 30(1), 3-8.

Fasina, O. E., Ologhobo, A. D., Adeniran, G. A., Ayoade, G. O., Adeyemi, O. A., Olayode, G., \& Olubanjo, O. O. (2004). Toxicological assessment of Veronia amygdaliana leaf meal in nutrition of starter broiler chicks. Nigerian Journal of Animal Production, 31, 3-11.

Fatokun, B. O., Aguihe, P. C., Osaguona, P. O., \& James, Z. (2013). Performance, carcass characteristics and haematological indices of cockerel chickens fed diets containing graded level of raw Gmelina arborea seed meal. International Journal of Agriculture and Biosciences, 2(5), 202-205.

Harbone, J. B. (1998). Methods of extraction and isolation 'phytochemical methods'. 3rd edition. Chapman and Hall, London, Pp. 60-66.

Hemid, A. E. A., El-Gawad, A. A., El-Wardany, I., El-Daly, E. F., \& El-Azeem, N. A. (2010). Alleviating effect of some environmental stress factors on productive performance of laying quail. 2. Laying performance. World Journal of Agricultural Sciences, 6(5), 517-524.

Hubrecht, R., \& Kirkwood, J. (2010). The UFAW Handbook on the Care and management of laboratory and other research Animals. John Wiley and sons. Pp. 655 - 674.

Iswarya, S., Sridevi M., \& Mayavel, A. (2017). Comparative study on phytochemical and antioxidant properties of Gmelina arborea Roxb. from four different geographical regions. International Journal of Pharmaceutical and Clinical Research; 9(4), 275-280.

Lima, H. J. D., Barreto, S. L. T., Donzele, J. L., Souza, G. S., Almeida, R. L., Tinoco, I. F. F., \& Albino, L. F. T. (2016). Digestible lysine requirement for growing Japanese quails. The Journal of Applied Poultry Research, 25(4), 483491.

Lin, Y. F., Chang, S. J., \& Hsu, A. L. (2004). Effects of supplemental vitamin $E$ during the laying period on the reproductive performance of Taiwan native chickens. British Poultry Science, 45(6), 807-814.

Momoh, O. M., Gambo, D., \& Dim, N. I. (2014). Genetic parameters of growth, body, and egg traits in Japanese quails (Cotournix cotournix japonica) reared in southern guinea

savannah of Nigeria. Journal of Applied Biosciences, 79(1), 6947-6954.

Murakami, A. E., Moraes, V. M. B., Ariki, J., Junqeira, O. M., Kronka-Sda, N., Barbosa-da-Moraes, V. M., \& NascimentoKronka, D. (1993). Level of protein and energy diets for laying Japanese quail (Coutrnix coutarnix japonica). Brazilian Journal of Poultry Science, 22(4), 541-551.

Nieman, D. C., Butterworth, D. E, \& Nieman, C. N. (1992). Nutrition. W M C. Brown Publishers, Dubuque.

Njoya, J. (1995). Effect of diet and natural variations in climates on the performance of laying hens. British Poultry Science, 36(4), 537-554.

NRC (1994). Nutrient Requirement of Poultry. National Research Council. Washington, USA, Pp. 41-54.

Nworgu, F. C., Oduola, O. A., Alikwe, P. C., \& Ojo, S. J. (2012). Effects of basil (Ocimum gratissimum) leaf supplement on initiation of egg laying and egg quality parameters of growing pullets. Journal of Food, Agriculture and Environment, 10(2
Part 1), 337-342.

Obike, O. M., Oke, U. K., \& Azu, K. E. (2011). Comparison of egg production performance and egg quality traits of pearl and black strains of guinea fowl in a humid rain-forest zone of Nigeria. International Journal of Poultry Science, 10(7), 547551.

Okagbare, G. O., Akpodiete, O. J., Esiekpe, O., \& Onagbesan, O. M. (2004a). Evaluation of Gmelina arborea leaves supplemented with grasses (Panicum maximum and Pennisetum purpureum) as feed for West African Dwarf goats. Tropical animal health and production, 36(6), 593-598.

Okagbare, G. O., Nwokoro, S. O., \& Onagbesan, O. M. (2004b). Protein and energy requirements of pre-weaned West African Dwarf goats fed soyabean diet as a replacement for milk in a tropical environment. Tropical Animal Health and Production, 36(6), 547-555.

Okpara, O., Akpodiete, O. J., \& Okagbare, G. O. (2016). Nutritional appraisal of processed Gmelina arborea leaves as feed of livestock. Journal of Agriculture \& Food Environment, 3(1), 61-65.

Osakwe, L. L. (2003). Effect of dried Morinda lucida supplementation on nitrogen and energy retention of sheep fed basal hay diet. Proceeding of the 28th Animal Conference of the Nigerian Society for Animal Production, Institute of Agricultural Research and Training, Obafemi Awolowo University, Ibadan, 28, 263-265.

Salah Uddin, M., Tareque, A. M. M., Howlider, M. A. R., \& Jasimuddin Khan, M. (1991). The influence of dietary protein and energy levels on egg quality in starcross layers. AsianAustralasian Journal of Animal Sciences, 4(4), 399-405.

Saraswati, T. R., Manalu, W., Ekastuti, D. R., \& Kusumorini, N. (2013). Increased egg production of Japanese quail (Coturnix coturnix japonica) by improving liver function through Tumeric powder supplementation. International Journal of Poultry Science, 12(10), 601-614.

Song, K. T., Chio, S. h. \& Ho, H. R. (2000). Comparison of egg quality of pheasant, chuker, quail and guinea fowl. Asian Australasian Journal of Animal Sciences, 13(7), 986-990.

SPSS (2007). Statistical package for Social Science. Release 17.0. User Manual. Microsoft Corp; U.S.A.

Thomas, K. S., Jagatheesan, P. R., Reetha, T. L., \& Rajendran, D. (2016). Nutrient composition of Japanese quails egg. International Journal of science, Environment and Technology, 5(3), 1293-1295.

Tuleun, C. D., \& Dashe, N. A (2010). Effect of dietary levels of toasted mucuna seedmeal (TMSM) on the performance and egg quality parameters of laying Japanese quail (Coturnix coturnix japonica). International Journal of Poultry Science, 9(12), 1092-1096.

Tuleun, C. D., Adenkola, A. Y., \& Yenle, F. G. (2013). Performance and erythrocyte osmotic membrane stability of laying japanese quails (coturnix coturnix japanica) fed varying dietary protein levels in a hot-humid tropics. Agriculture and Biology Journal of North America, 4(1), 6-13.

Tunsanrinkan, T., Tungjaroenchai, W., Sirwong, W., (2013). Nutrient benefit of quail (Coturnix coturnix japonica) eggs. International Journal of Scientific and Research Publications, 3(5), 1-8.

Yamane, T., Ono, K., \& Tanaka, T. (1979). Protein requirement of laying Japanese quail. British Poultry Science, 20(4), 379383. 